\title{
Uppal air Siltometer
}

\author{
IBY \\ Dr. H. L. UPPAL \& GAJÏNDER SINGH \\ M. Sc., PH. D. \\ M. Sc.
}

Texte français, p. 859.

\section{INTRODUCTION}

The question of sediment load in natural streams and in a canal system has assumed great importance in recent years. Several cooperative studies have (1) been made for the determination of deteritus load in rivers and canals and the information collected has been usefully applied in designing desilting measures.

In Punjab regular silt surveys of the canal systems of the province started in the year 1935-1936. In each survey a large number of samples had to be collected from the main lines, branches and distributaries and analysed to construct their size distribution curves. In order to analyse the sand samples Vaidhianathan (2) and Puri (3) developed siltometers. Both these instruments had limitations. Vaidhianathan's siltometer though fairly accurate could not be used for routine and quick sand analysis. Besides, special mountings for the apparatus were required to eliminate vibralions, and the apparatus had to be housed in a special room. Puri siltometer though robust did not give necurate results. A small number of samples would only be analysed in a day with either of Huwe sillometers. The calculations, after analydiv for constructing the size distribution curve, whe libourious and time-taking.

The necessity for a quick and accurate apparatus for silt analysis was greatly felt. In order to meet this demand a new siltometer was developed using air as a medium instead of water. The essential advantages of the new siltometer are:

(1) Cooperative studies on sediment by E. W. Lane \& others.

(2) Publication no. 1, Vol. V of Punjab Irrigation Research Institute, Lahore.

(3) Pub. No, 7, Vol. II of I.R.I., Lahore.
1. It gives directly the size distribution curve thus avoiding length mathematicil calculations.

2. A very large number of samples can be analysed in a day.

3. The analysis is accurate.

The idea of using air for analysis of sand occurred one evening while on tour at Sagar Rest House in 1938 in connection with the inspection of silt survey work of the Lower Chenab Canal, East Circle.

After the siltometer had been developed and published in 1939 (4) a paper appeared in Civil Engineering on wind tunnel classifier for sand and silt by Otto and Rouse (5). They developped an apparatus for classifying various sands and silts.

As already mentioned the main object of the siltometer was to directly obtain accurate size distribution curve of a sample which warranted an elaborate calibration, etc, of the apparatus.

\section{Principle}

The air siltometer utilizes the fact that the sand particles when dropped across a horizontal stream of air separate out and distribute themselves according to their sizes i.e. according to the diameter of their equivalent spheres having the same density and velocity of fall. The heavier particles fall nearer the origin and the lighter ones fall farther away.

(4) Annual Report of Punjab Irrigation Research, Lahove, 1939.

(5) "Wind Tunnel classifier for sand and Silt", by otto and Rouse. "Civil Engineering", Vol 9, pp. 414415, July 1939. 


\section{Description of the Apparatus}

The new siltometer comprises the following important parts.

1. An electric blower.

2. Stilling chamber and lead chamber.

3. Experimental Tank.
a) Air tunnel.
b) Collecting chambers.

A blower, coupled to an electric motor, sends out a continuous current of air at a uniform rate. The speed of air is maintained by regulating the speed of the motor through a system of rheostats.
The blast of air spreads out as it enters the stilling chamber which has glass sides. The turbulence caused in the stream due to expansion is stilled down by passing it through a set of honey combs designed for the purpose. It further becomes smooth and uniform as it enters the lead chamber where its airway contracts from $2.0^{\prime \prime}$ to $1 / 4^{\prime \prime}$.

\section{Experimental tank}

The experimental tank is made of two glass plates $4.0^{\prime} \times 3.0^{\prime} \times 5 / 8^{\prime \prime}$. The upper $1.5^{\prime}$ of it is used as an air tunnel through which a uniform current of air flows in a horizontal

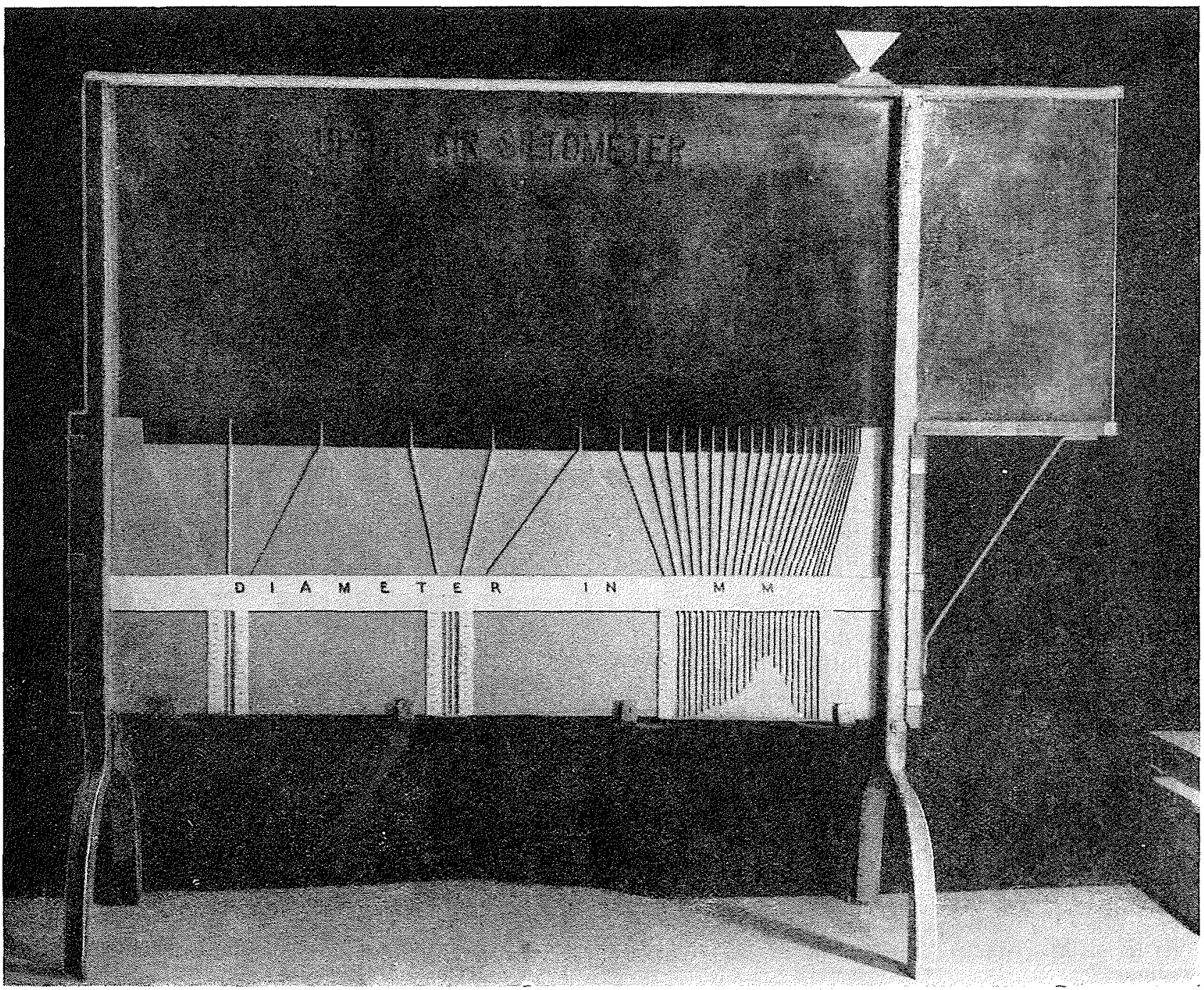

PLATE $x^{\prime \prime} 1$. - Eppal air siltometer showing a view of the collecting chamber. Siltometre à air d'Uppal montrant une vue des compartiments de réception. 
direction. The bottom of the air tunnel consists of a grid whose spacings have been determined experimentally. The grid is so designed as not to allow any particle to accumulate on its upper edges. The equi-spaced collecting chambers are calibrated to read directly the percentage by weight of the collected particles.

The boltom of the collecting chambers can be unfastened so that after an analysis, the sample can be readily taken out.

A specially designed silt dropping funnel is fitted at the top right corner of the air tunnel. It has a shutter fitted at its bottom which permits the silt to drop in a thin sheet across the section.

A centigrade thermometer is provided in the

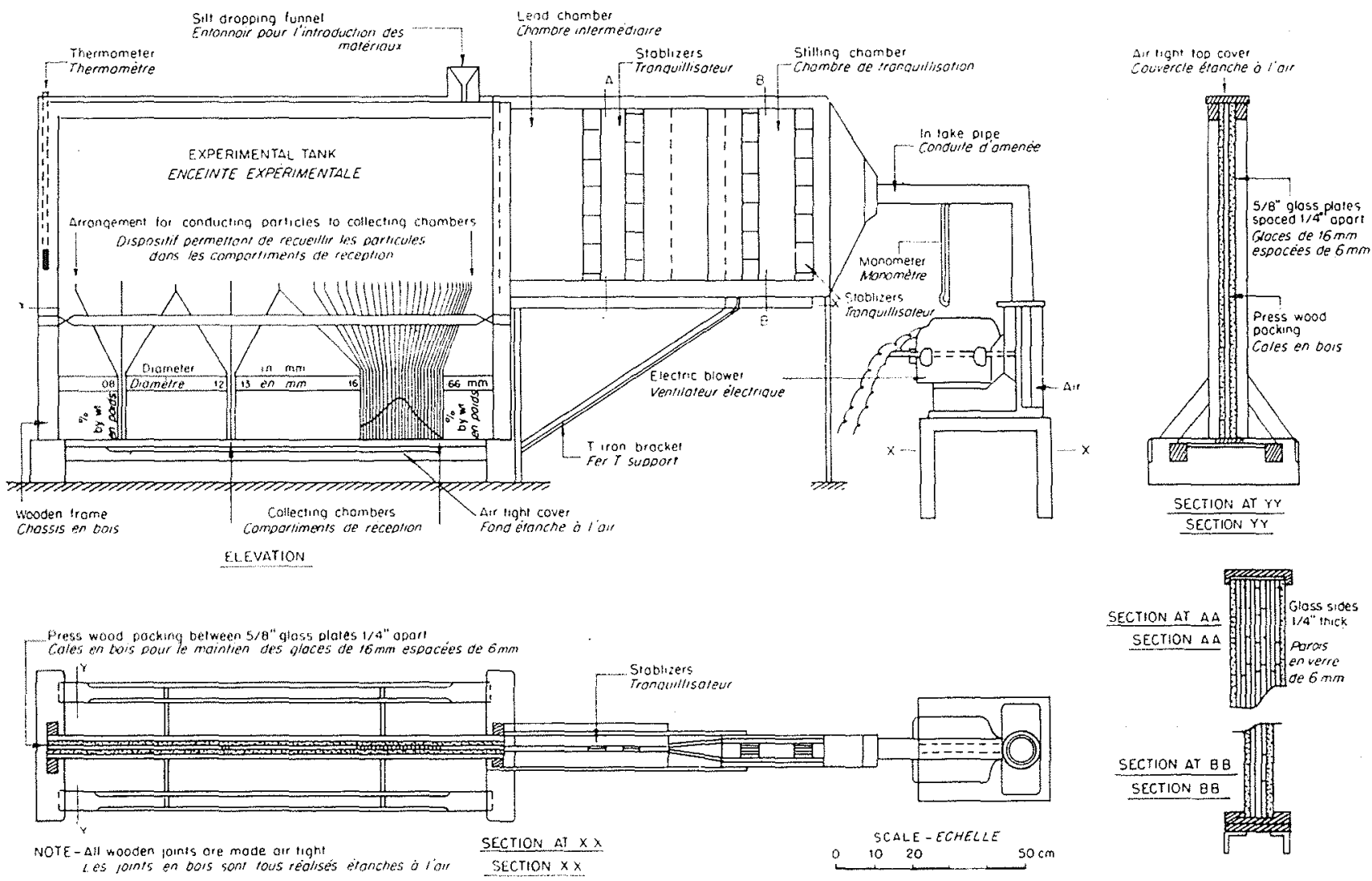

Fia. 1. - Uppal's air siltometer.

Siltomètre à air d'Uppal.

airway at the end of the tunnel which reads the temperature of the out going air. The different parts of the apparatus are shown in Fig. 1.

\section{Procedure}

A thoroughly air dried silt sample is screened through a sieve of 20 mesh so as to remove foreign matter. A weighed quantity of sand is put in the funnel. After adjusting the speed of the blower, the shutter of the funnel is opened. The particles separate out and collect in their respective collecting chambers at the bottom. A direct size distribution curve is obtained as shown in Fig. 1 and Plate No 1.

\section{Calibration of the siltometer}

The calibration of the apparatus is the most important item and is done by the following method. A dried and screened sample is introduced and particles started out by the siltometer are collected at about fifteen different points at the bottom of the tank. Diameters of more than one thousand particles collected at a single point is observed under a high power microscope both along the axis of $\mathrm{X}$ and the axis of $\mathrm{Y}$. A mean of these observations give the average mean diameter of the particles falling at that point. The horizontal distance of this point from the dropping point is measured accurately and the observations repeated several times. Finally a curve is plotted between the 


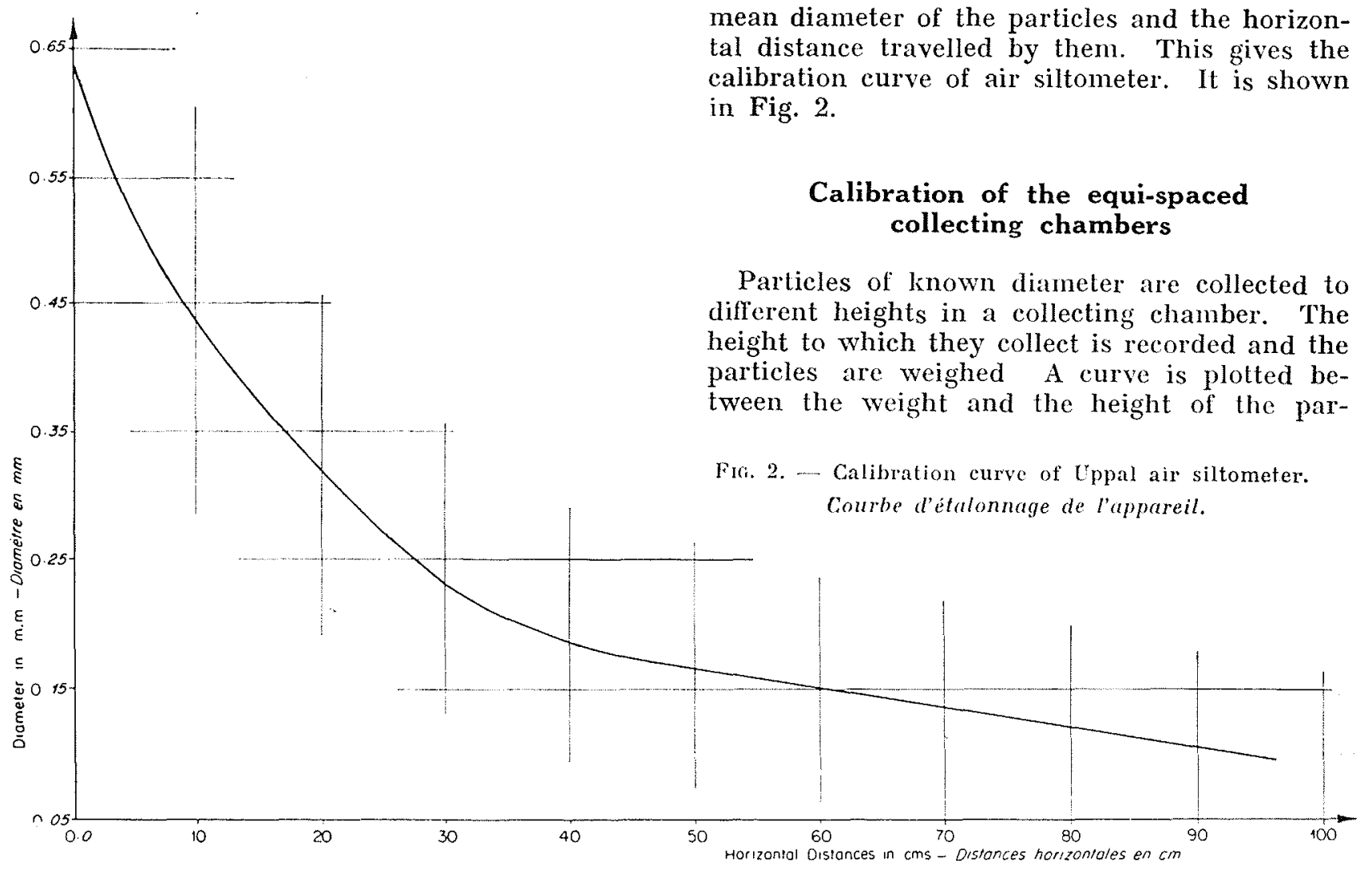

ticles. This operation is repeated with particles of different diameters. A plot of the observations is shown in Fig. 3. Finally a mean of all these curves is prepared and from this curve weight per $\mathrm{cm}$ height of parlicles is calculated.

Knowing this and the total weight of the sample percentage by weight per $\mathrm{cm}$ height of collecting chambers is obtained.

In order to examine the accuracy of the siltometer following tests were carried out.

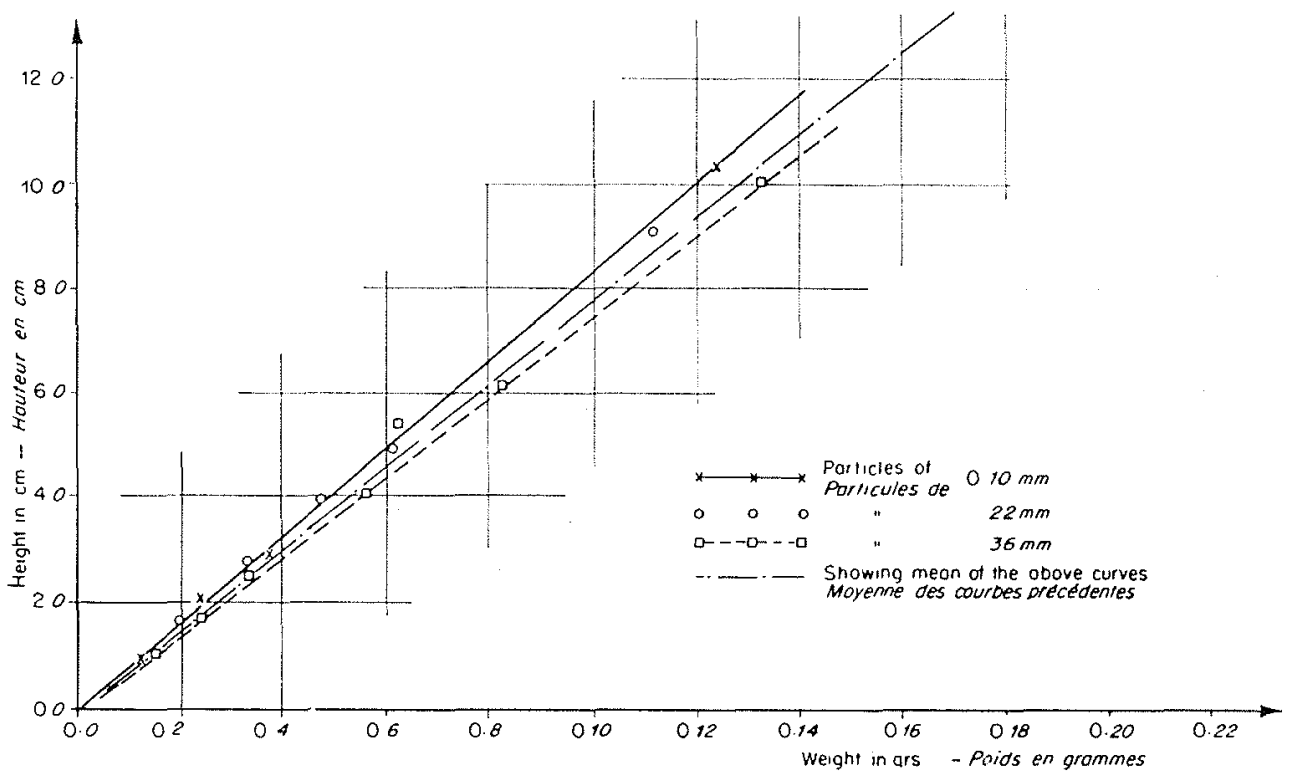

Fig. 3. - Showing weight of particles of different diameters collected to different heights.

Conrbes donnant, en fonction des hauteurs de l'échantillon recueilli, les poids des particules d'un diamètre donné. 


\section{Reproducibility}

A. - A weighed quantity of a well mixed silt sample is introduced and size distribution curve obtained. The same sample is put in again to see whether or not the size distribution curve reproduces itself. From a large number of tests carried out it was shown that the curve is correctly reproduced.

The reproducibility of the curve in one case is shown in Fig. 4.

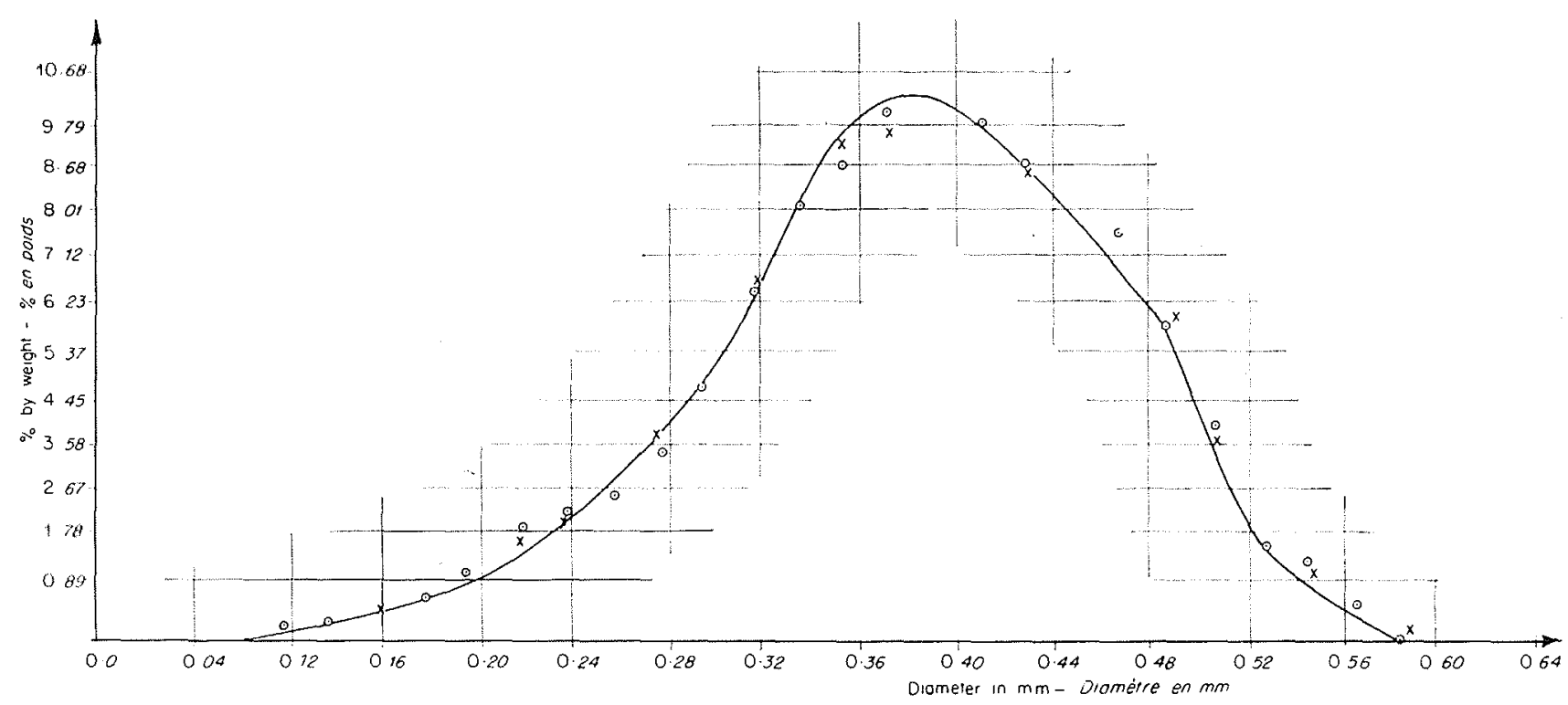

Fuc. 4. - Size distribution curves showing the reproducibility of the siltometer.

Courbes granulometriques montrant la fidélité de lappareil.

\section{Reproducibility of size distribution curve of a silt sample analysed \\ with different quantities of the sample}

B. - A known quantity of a sample was in- troduced in the sillometer and its size distribution curve obtained.

In the second experiments double the quantity was taken and a size distribution curve plotted by taking half the observed value of per-

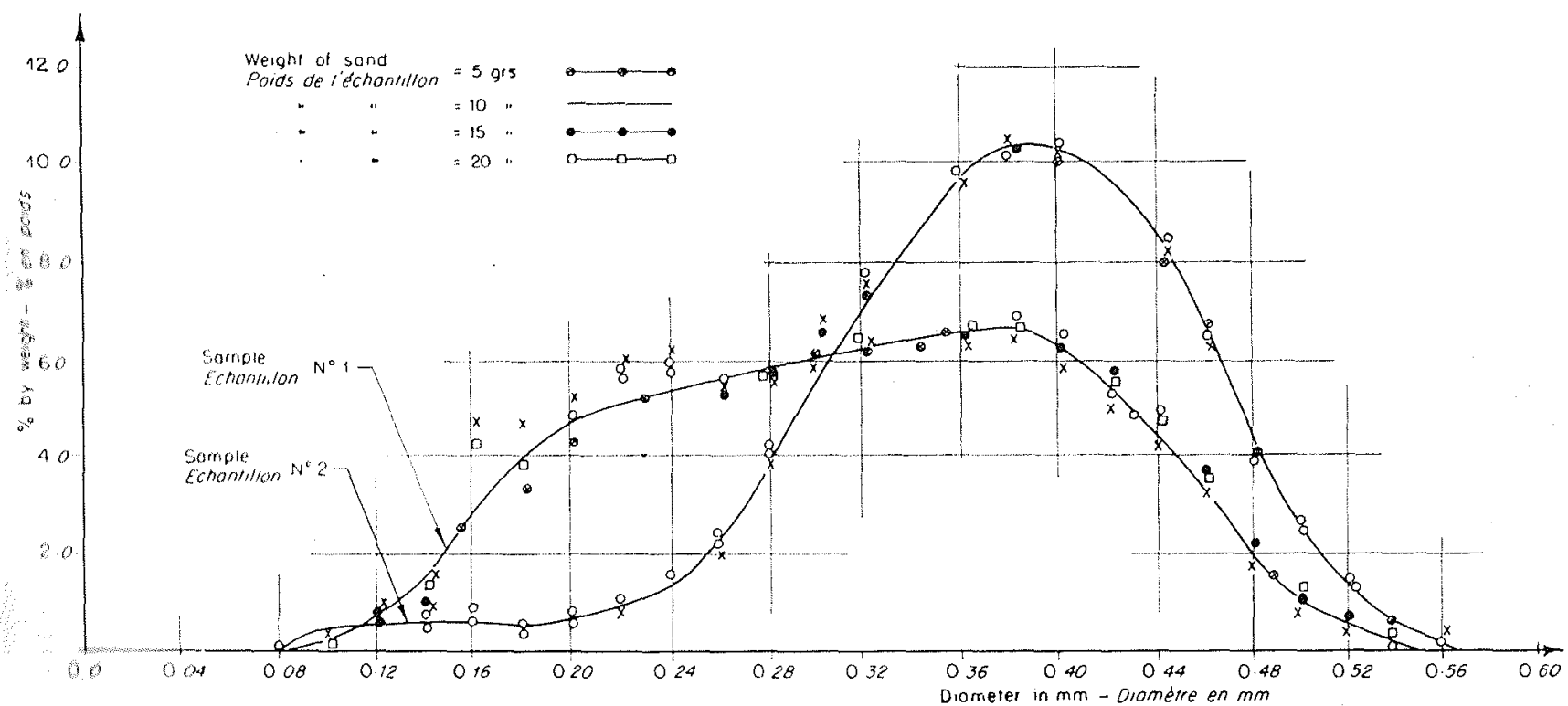

Fic, 5. Showing the reproducibility of size distribution curves of a particular sample when examined with different quantities.

Variation de la courbe granulométrique d'un échantillon déterminé snipant la quantité de cet echantillon soumise d̀ l'analyse. 
centage weight of particles collected in different chambers.

Next three times the original quantity was dropped and a curve plotted by taking one third the observed values of percentage weight of particles collected in different chambers. It was found that all the three curves closely agreed with each other. This is shown in Fig. 5 .

C. - Equal quantities of two samples, one fine sand and the other a little coarser were taken. They were introduced in the siltometer in turn and their respective size distribution curves were obtained. These are shown in Fig. 6 at $a$ ), $b$ ).

A curve was then plotted by taking the algebric sum of these curves. It is shown at " $\mathrm{C}$ " in the same diagram. Then a mixture of these two samples was introduced by taking equal quantity of each and the size distribution curve so obtained was plotted as shown in Fig. 6 at D. It was observed that this curve agrees very well with the algebric sum curve; thus confirming the accuracy of the apparatus for silt analysis.

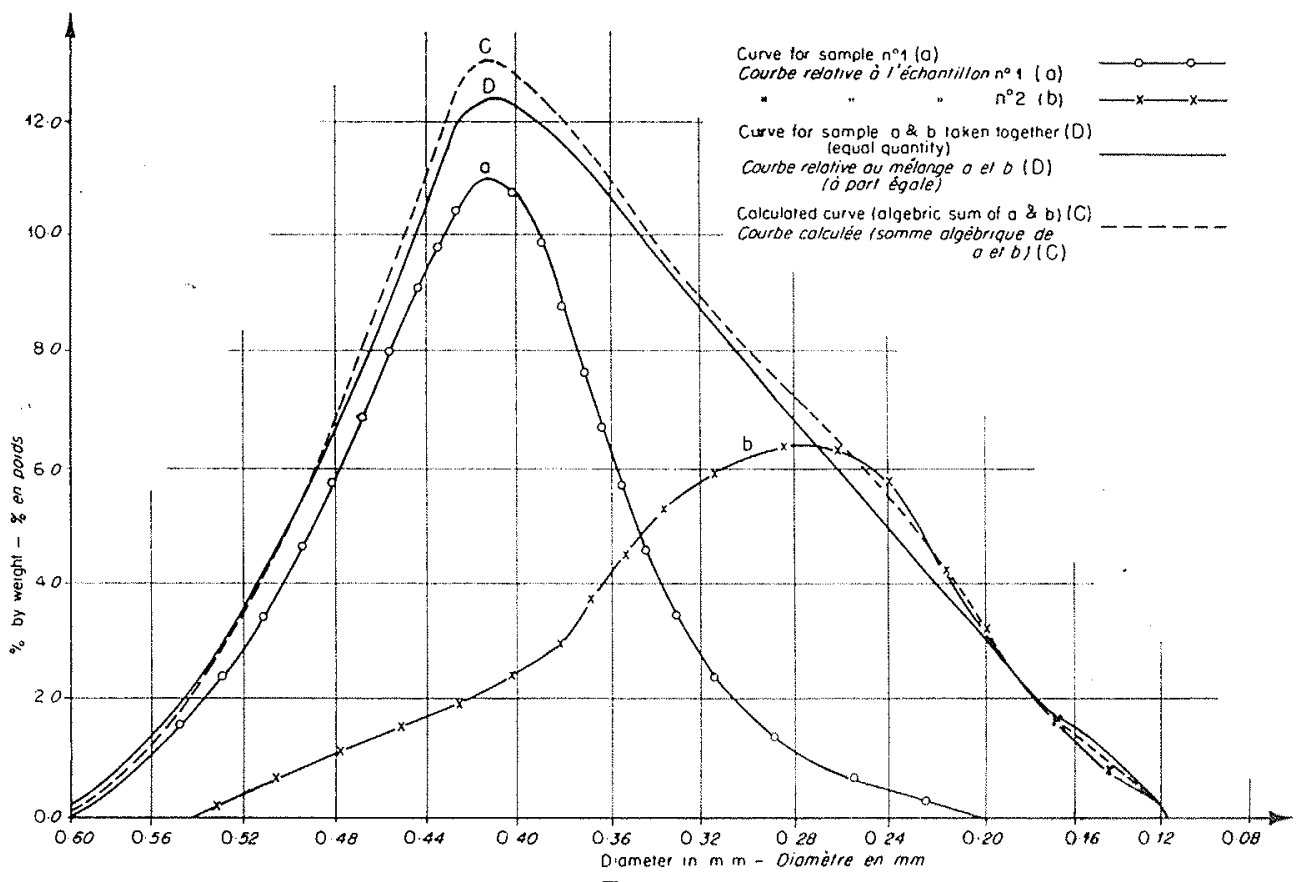

FIG. 6.

\section{A comparison of the results obtained with air siltometer with those obtained on other siltometers in use}

It was decided to compare the working and accuracy of the three siltometers i.e. the Optlcal Level, The Puri and Uppal siltometer. In order to do this eight samples were analysed simutaneously on all the three siltometers and the size distribution curves were prepared.

A plot of the curves obtained from different siltometers for these samples is shown in Fig. 7 to 14 . The average mean value of diameter of particles of the samples was computed from their respective size distribution curves. The average mean value of diameters of different samples obtained by different siltometers, is given in the opposite table:

\begin{tabular}{|c|c|c|c|}
\hline \multirow{3}{*}{ SAMPLE No. } & \multicolumn{3}{|c|}{$\begin{array}{c}\text { AVERAGE MEAN } \\
\text { DHAMETH } \times 102 \mathrm{~mm} \text { AS DETERMD }\end{array}$} \\
\hline & $\begin{array}{l}\text { Optical } \\
\text { level. }\end{array}$ & Puri. & $\begin{array}{l}\text { Uppal } \\
\text { Air. }\end{array}$ \\
\hline & \multicolumn{3}{|c|}{ SHTOMETERS. } \\
\hline Sample No. 1. & 32.22 & 31.04 & 32.52 \\
\hline Sample No. 2. & 31.44 & 25.86 & 29.46 \\
\hline Sample No. 3. & 19.30 & 16.74 & 19.36 \\
\hline Sample No. 4. & - & 13.88 & 17.08 \\
\hline Sample No. 5. & 44.76 & 42.03 & 39.34 \\
\hline Sample No. 6 . & 37.86 & 30.84 & 32.32 \\
\hline Sample No. 7 . & $28.0 \div$ & 23.57 & 26.28 \\
\hline Sample No.8. & 33.60 & 27.66 & 31.10 \\
\hline
\end{tabular}




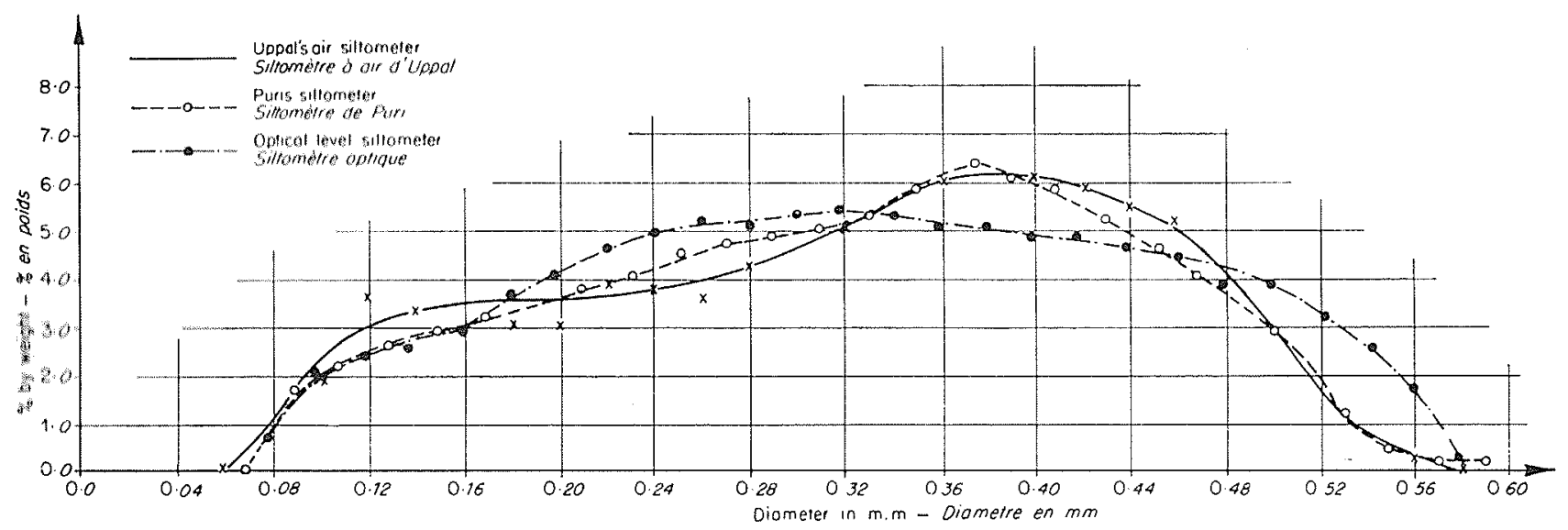

Fig. 7. - A comparison of size distribution curves. Sample $n^{\circ} 1$.

Comparaison des conrbes granulométriques obtenues avec divers appareils. Echantillon $n^{\circ} 1$.

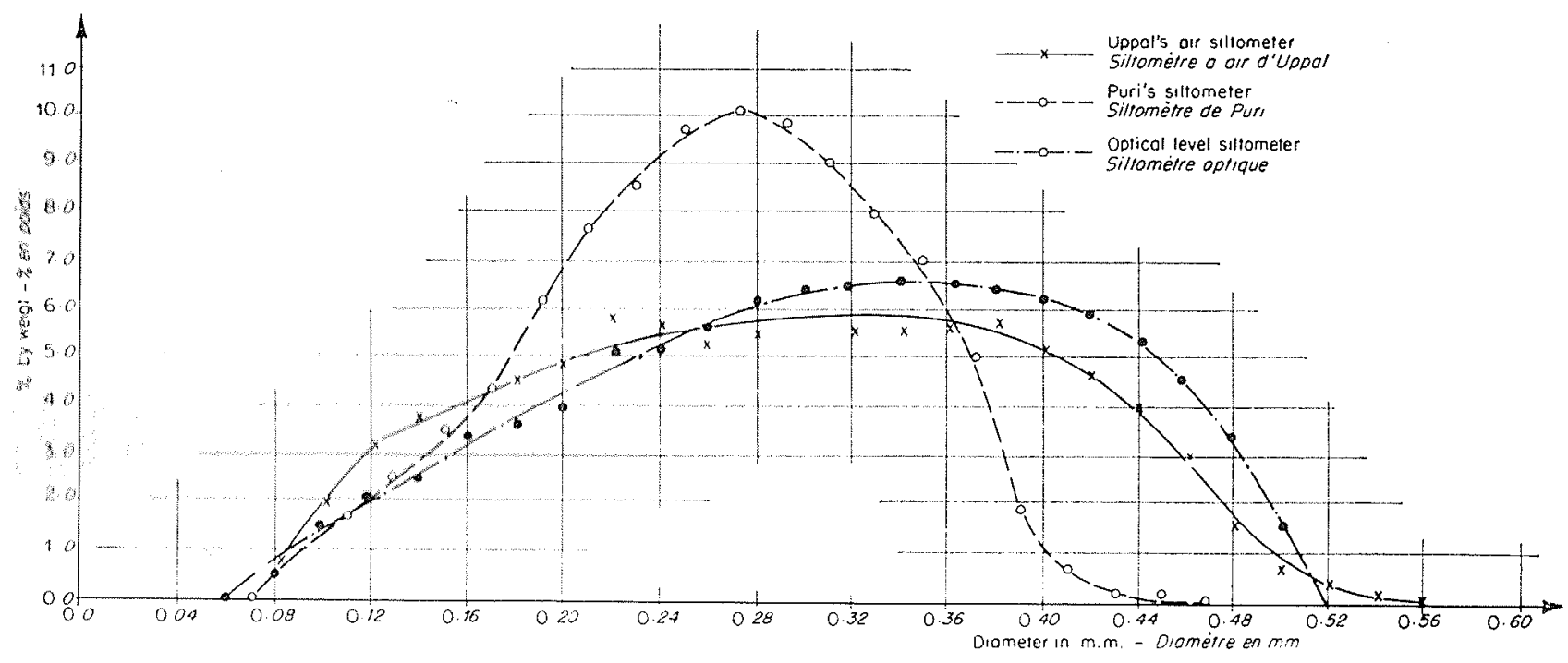

Fig. 8. - A comparaison of size distribution curves. Sample $n^{\circ} 2$.

Comparaison des courbes granulométriques obtenues avec divers appareils, Echantillon $n^{\circ} 2$.

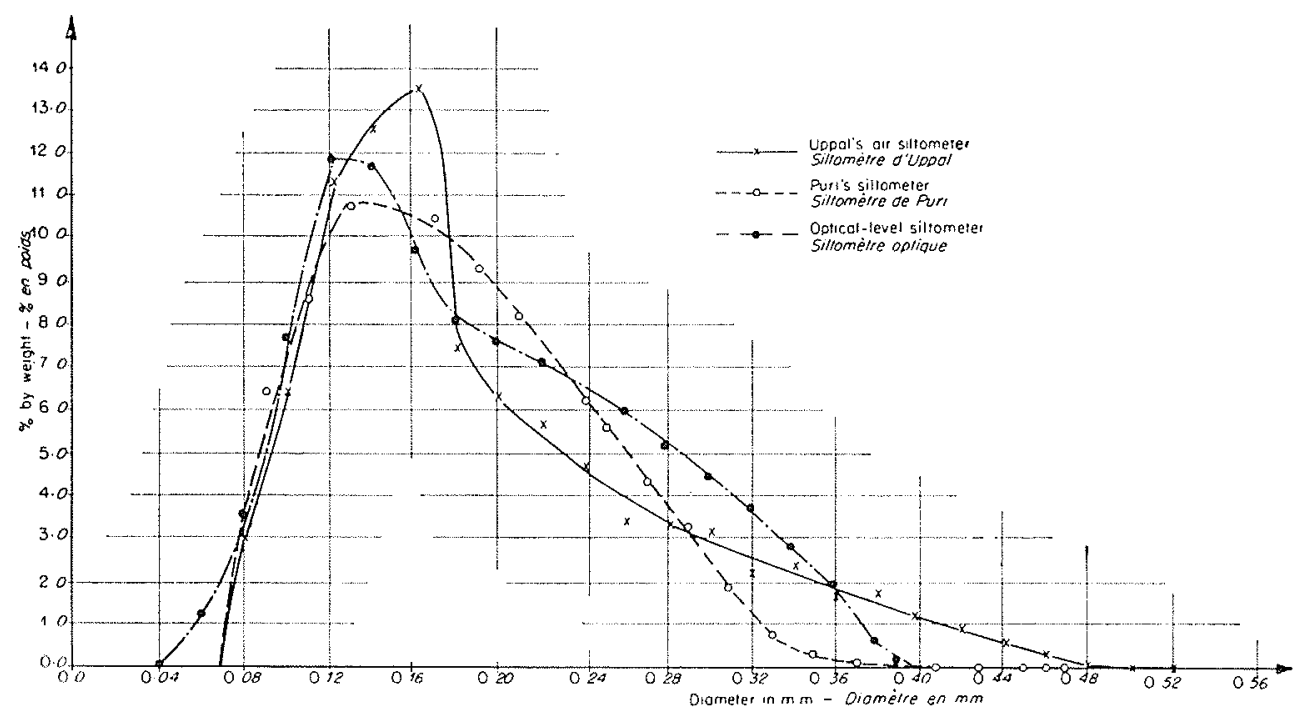

Frg. 9. - A comparaison of size distribution curves. Sample n०3.

Comparaison des conrbes granulométriques obtenues avec divers appareils. Echantillon $n^{\circ} 3$. 


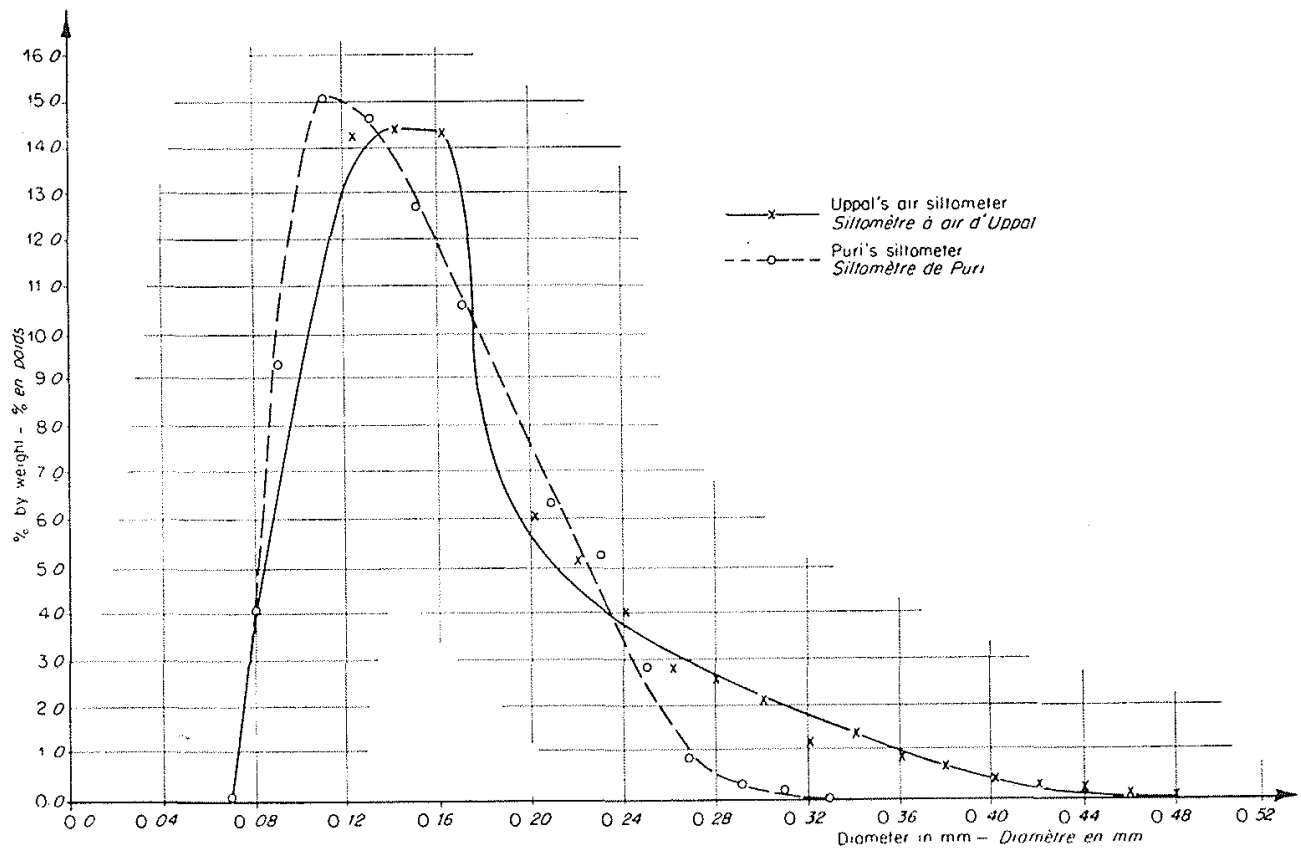

Fig. 10. - A comparaison of size distribution eurves. Sample $n^{*} 4$.

Comparaison des conrles granulométriques obtenues anec divers appareils. Echantillon $n^{\circ}$ is.

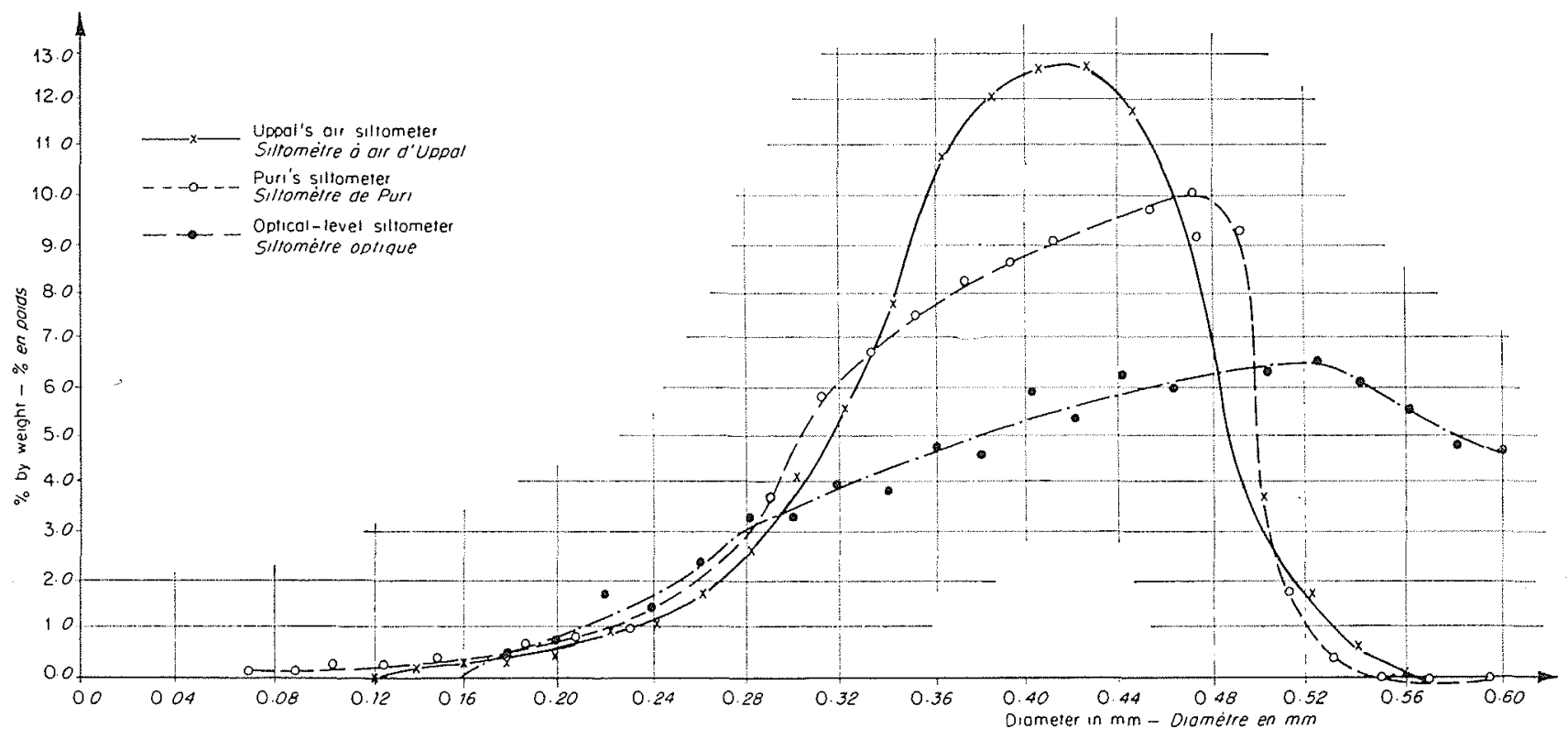

FIG. 11. - A comparaison of size distribution curves. Sample no 5 .

Comparaison des courbes granulométriques obtenues avec divers appareils. Echantillon $n^{\circ} 5$. 


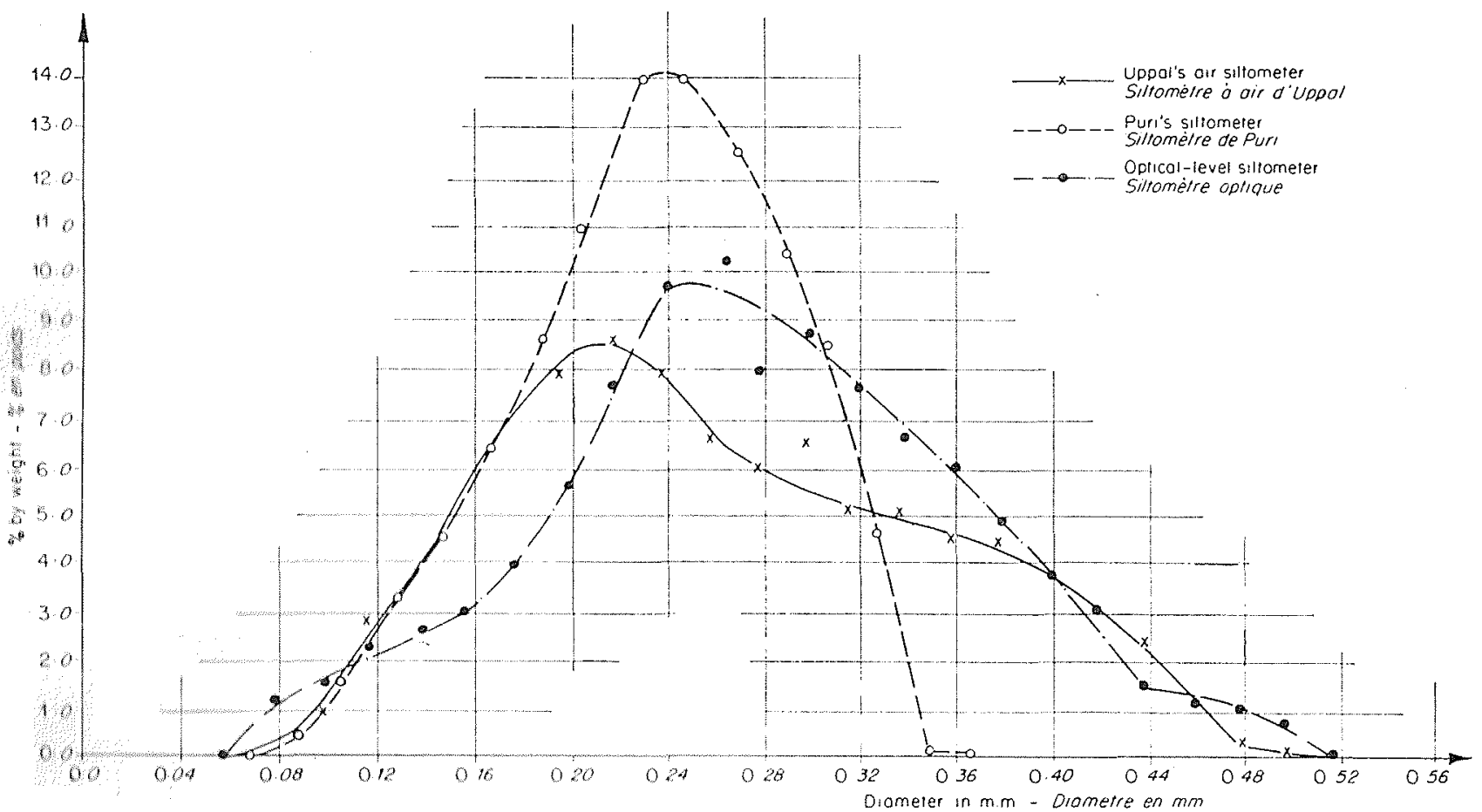

Hia. 12, A compantanon of size distribution curves. Sample $n " 6$.

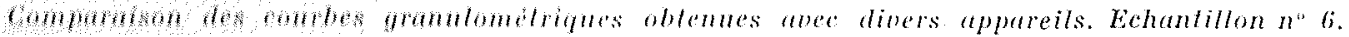

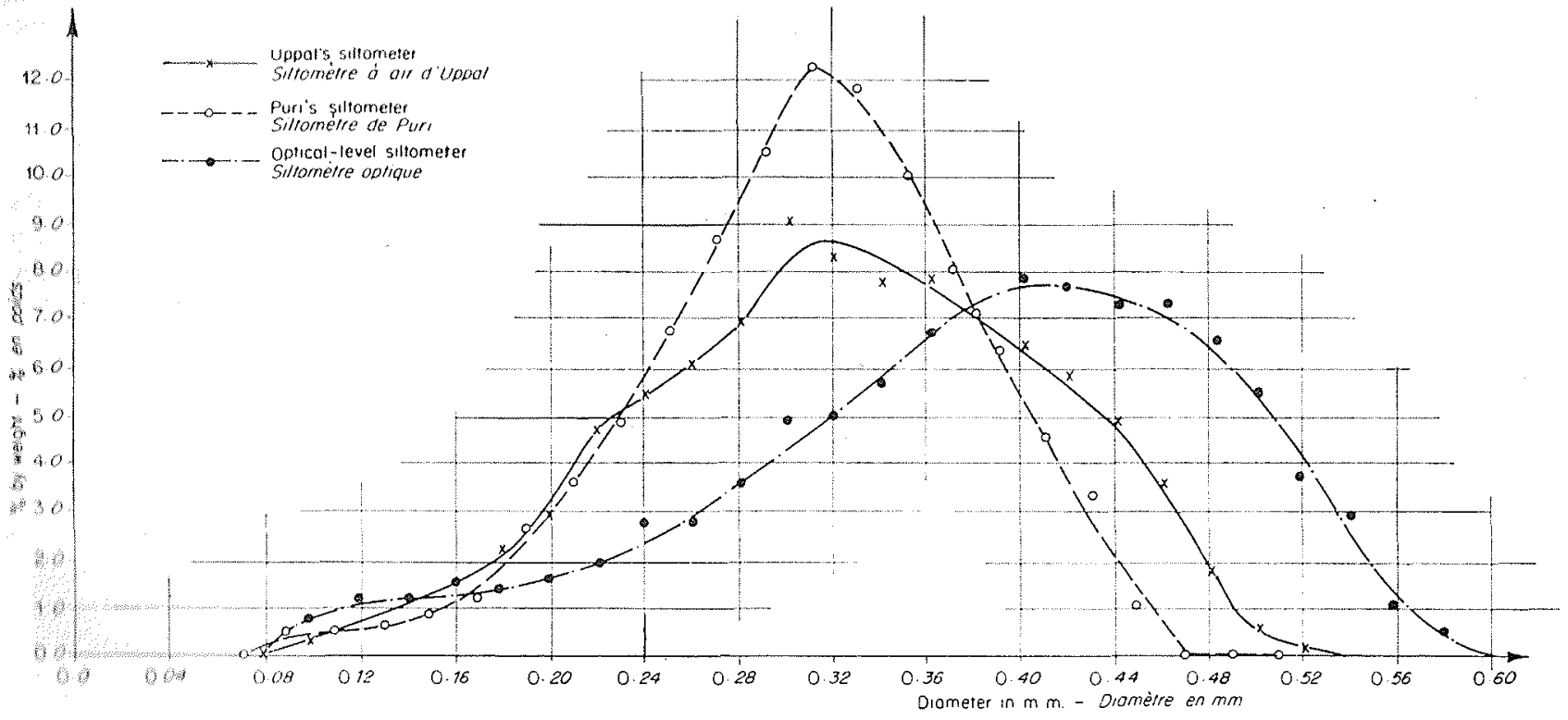

Fic. 13. - A comparaison of size distribution curves. Sample n" 7 .

Comparatson des conrbes granulometriques oblenues abec divers appareils. Echantillon $n^{\circ} 7$. 


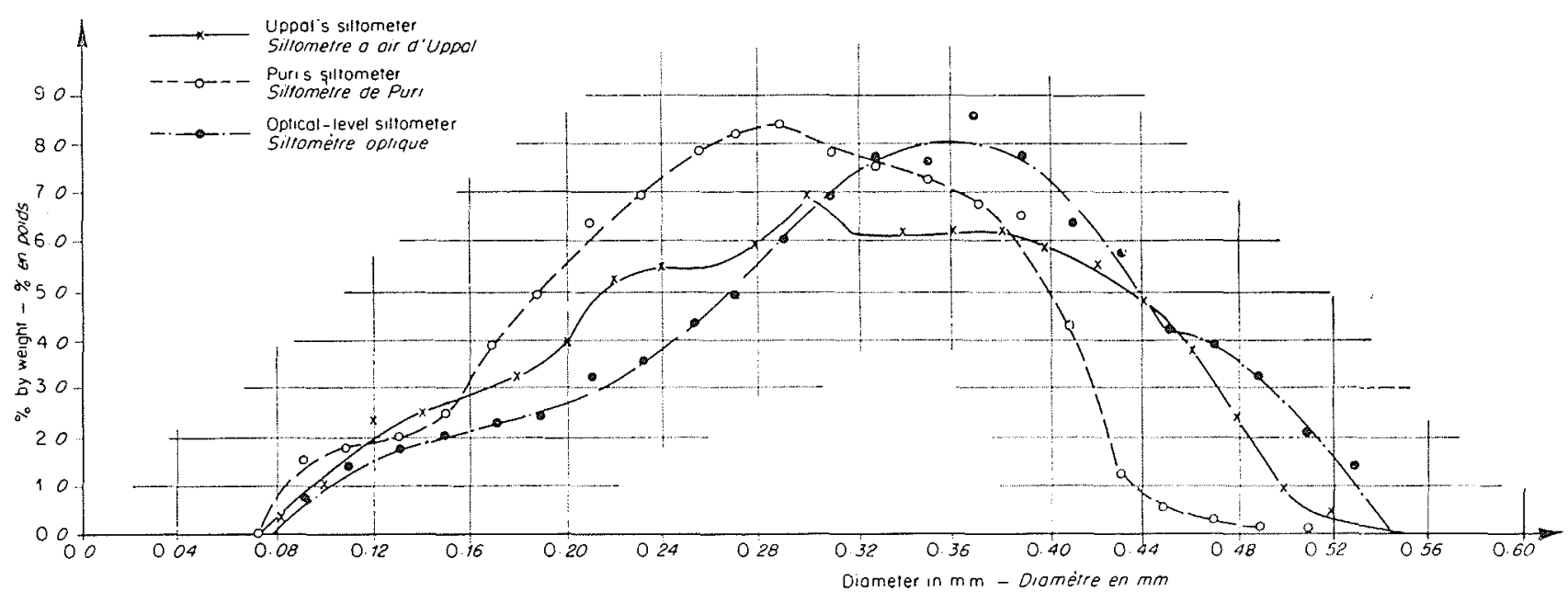

Fra. 14. - A comparaison of size distribution curves. Sample $n^{0} 8$.

Comparaison des courbes granulométriques obtenues avec divers appareils. Echantillon $n^{\circ} 8$.

\section{Effect of temperature}

The effect of temperature on the working of the air siltometer was examined. It was shown that the size distribution curve of the same sample reproduced itself when examined under different temperatures of air. A difference of $30^{\circ} \mathrm{C}$ in temperature appeared to have no influence.

At certain silt sites where the electric current is not available the air blowing arrangement has been modified. A hand blower has been fitted and the apparatus has given reasonably accurate results with experienced hands.

The working of the apparatus was demonstrated to the Punjab Chief Engineers in 1940 December who liked the instrument and ordered its official use for silt analysis. Certain refinements were made in the frame of the instruments. It was made much lighter by using aluminium frame.

The working of the apparatus was specially demonstrated to the various Engineers from outside who came to attend the meeting of the Punjab Engineering Congress in 1941. They examined the working of the apparatus with different grades of material and thoroughly satisfied themselves. Among the people who examined the siltometer critically were Mr. Gerald
Lacey, Sir Claude Inglis, Dr. Bose, Mr. Haus, Chief Engineer Sind, and Mr. K. K. Framjee, X.E.N. Development Sind, later, Director, Central Water Power, Irrigation, Navigation Research Station; Poona. Soon after requisitions for the supply of siltometer, were received from Sir Claude Inglis, Mr. K. K. Framjee and others.

Facilities available in the workshop at Lahore did not permit many siltometers to be made and supplied. The detailed drawings of the instruments were however sent to them, so that they could get the siltometer made at their own places.

At the request of the Secretary, Central Board of Irrigation, the apparatus was exhibited in the All India Exhibition of the Central Board of Irrigation held at New-Delhi in 1946.

One of the authors in his tour of U.S.A. and U. K. in 1946 had the opportunity of discussing this apparatus with eminent sediment specialists such as Prof. Lane and Hunter Rouse of Iowa Institute of Hydraulic Research and many others. They showed their keen interest in this apparatus.

Attempts are being made to increase the working range of the instruments and also to further improve upon it. Instead of bloving air, arrangement is being made to exhaust air through the experimental tank. 


\title{
Siltomètre à air d'Uppal
}

\author{
PAR DR. H.L. UPPAL ET GAJÏNDER SINGH \\ M. Sc., Pн, D. M. Sc.
}

English text, p. 849 .

Pour les illustrations, se reporter au texte anglais p. 849.

\section{INT TODUCTION}

16 pobleme du transport solide dans les cours ovm noturels et dans les canaux revèt depuis quelfuo anness, the grande importance. De tres nombroux travaux ont contribué a la determination du deblt solide dans les rivieres ot les canaux et los ronseignements recuoilis ont oto fructueusement mis a profit pon la mise an point de dispositifs de decuntulion.

Qu lonjh, dephin 1986.1936 , les canaux sont

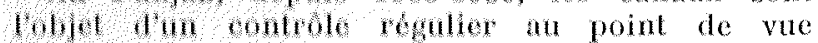
Hounorte sollow, Dang chaque cas, un grand nombro dechnthlons sont prélevés dans les canamx principaux, dans les secondaires et les tertialires; ces echantillons font ensuite l'objet d'une analyse granulométrique. Vamminatrax et PURr avaient mis au point des siltomètres permettant felfectuer ces analyses. Ces deux appareils ont des possibilités limitées. De plus, il convient d'adopter des montages spéciaux pour éviter toute vibration et les appareils doivent etre disposes dans une piece réservée. Le siltomètre Pun, bien que robuste, manque de précision. Chacun de ces appareils n'est à même d'analyser qu'un petit nombre dechantillons par jour. Une fois l'analyse faite, les calculs nécessaires à la détermination de la courbe ranulométrique sont longs et laborieux.

La necessitó d'un appareil, à la fois rapide et prédis pour lanalyse des échantillons, se faisait donc grandemont sentir. C'est à cet effet que nous avons mis au point un nouvel appareil dont l'originalité consiste ‘ utiliser, comme milieu, l'air au lieu de leat. Ses principaux avantages sont:

1" De donner directement la courbe granulométrique en évitant de longs calculs.

Do permettre l'analyse quotidienne d'un grand nombre d'échantillons.

Mokfor procis.

L thoo Andopler l'air pour l'analyse des dépôts, dato d'un wolr do 1938 a Sagar Rest House, au cours dune tounce d'inspection de la campagne de me- sure des concentrations, sur le Lower Chenal Canal, East Circle.

Ce siltomètre avait été réalisé et avait déjà fait l'objet d'une publication en 1939, lorsque parut, dans « Civil Engineering », sous la signature de OrTo et Rouse, un article décrivant un tunnel aérodynamique pour classer le sable et les vases.

Comme nous l'avons déjà indiqué, le principal but de ce siltomètre était d'obtenir directement une courbe précise traduisant la granulométrie d'un échantillon; ceci exigeait évidemment un étalonnage minutieux de l'appareil.

\section{Principe de fonctionnement}

Le siltomètre à air utilise le fait que les particules lancées par un courant d'air horizontal se séparent et se répartissent suivant leurs dimensions, c'est-àdire suivant le diamètre de la sphère ayant même densité et même vitesse de chute. Les particules les plus lourdes sont les premières à tomber, les plus légères vont le plus loin.

\section{Description de l'appareil}

Le nouveau siltomètre se compose principalement :

$1^{\circ}$ D'une soufflerie électrique;

$2^{\circ}$ D'une chambre de tranquillisation suivie d'une chambre intermédiaire;

$3^{\circ}$ D'une enceinte expérimentale comprenant:

a) Le tunnel aérodynamique;

b) Les compartiments de réception.

Un ventilateur entraîné par un moteur électrique produit un courant d'air continu à vitesse constante. La vitesse de ce courant d'air est maintenue en agissant sur la vitesse du ventilateur grâce à un jeu de rhéostats. 
Le jet d'air s'étale à son entrée dans la chambre de tranquillisation, dont les parois sont en verre.

La turbulence provoquée par ce mouvement est combattue par un système de filtres réalisés à cet effet. L'écoulement devient tranquille et uniforme lorscu'il pénètre dans la chambre intermédiaice oi lo canal se rétrécit pour passer de 50 à 6 millimètres.

\section{Enceinte expérimentale}

Cette enceinte est formée par deux parois en verre de $1,20 \mathrm{~m}$ sur $0,90 \mathrm{~m}$ et de $16 \mathrm{~mm}$ d'épaisseur. La partie supérieure, sur une hauteur de $45 \mathrm{~cm}$, constitue un tunnel aérodynamique. Le fond de ce conduit est constitué d'une grille dont les mailles ont été déterminées expérimentalement. Cette grille est réalisée de telle sorte qu'aucune particule ne peut se maintenir sur ses bords. Les compartiments de réception ont été dimensionnés de facon que l'on puisse lire directement le pourcentage en poids des particules recueillies.

Les compartiments de reception sont munis d'un fond amovible, ce qui permet, une fois une analyse terminée, de retirer facilement l'échantillon.

Un petit entonnoir à matériau est disposé au coin supérieur droit du tunnel aérodynamique. Grâce à un robinet, cet entonnoir permet de faire tomber les matériaux dans l'écoulement en une nappe très fine.

Un thermomètre placé à l'extrémité aval du tunnel donne la température de l'air à sa sortie de l'appareil. La figure 1 montre les divers aspects de cette installation.

\section{Mode d'uthilisation}

L'échantillon, après avoir été soigneusement séché a l'air, est passé au tamis de 20 mesh afin d'en retirer les corps étrangers. On dispose alors dans l'entonnoir un poids déterminé de matériaux. Une fois la vitesse du ventilateur réglée, on ouvre le robinet de l'entonnoir. Les particules se séparent et se rassemblent dans leur compartiment de réception respectif, au fond. Comme le montrent la figure 1 et la photographie, on obtient alors directement une image de la courbe granulométrique.

\section{Etalonnage de l'appaxeil}

Cette opération est extrêmement importante et se réalise de la facon suivante.

Après avoir introduit un échantillon sec et tamisé, on recueille, en une quinzaine de points différents du fond, les particules triées par l'appareil. Dans chacun des petits tas recueillis, on prélève an moins une douzaine de particules dont on mesure au microscope des diamètres principaux suivant deux directions $\mathrm{X}$ et $\mathrm{Y}$. La moyenne de ces mesures indique le diamètre moyen des particules tombant au point considéré. La distance horizontale séparant ce point du point de départ fait l'objet d'une mesure rigonreuse, et ces observations sont répétées à plusieurs reprises. Finalement, on trace une coumbe donnant, en fonction de leur longueur horizontale de parcours, le diametre moyen des particules. Ceci constitue la courbe d'étalonnage de l'appareil telle qu'on peut la voir sur la figure 2.

\section{Etalonnage des compartimemîs de récepion}

Des particules de diamètre connu se rassemblent sur une certaine hauteur dans l'un des compartiments de réception. Cette hauteur est mesurée et les particules sont pesées; on trace alors la courbe poids-hauteur, et l'on répète ces opérations avec des particules de divers dianetres. La figure 3 fournit un exemple de ces observations. On peut en déduire une courbe moyenne permettant de calculer le poids du dépôt en fonction de sa hauteur. Ceci etant, si l'on connait le poids lotal de l'echantillon, la mesure de la hauteur des dépôts dans les compartiments de réception donne le pourcentage en poids.

Afin d'examiner la précision de l'appareil, los essais ci-dessous furent exécutés.

\section{Fidélizé}

On introduit un poids donné d'un echantillon de matériaux soigneusement mélangés, et l'on obtient une première courbe granulométrique. Le même échantillon est introduit à nouveau, afin de voir si la courbe granulométrique se reproduit identique. Un grand nombre d'expériences ont démontré que la courbe se reproduisait correctement. Un exemple en est donné sur la figure 4.

\section{Vartations de la conrbe granulométräque d'un échantillon déterminé, Suivvant lex quantiłé de cet échantillon soumise à $1^{\prime}$ carcilyse}

Après introduction d'une quantité connue d'un echantillon, on relevait la courbe granulométrique donnée par lappareil.

Dans une seconde experience, on doublait la quantité introduite, ef on tracait une courbe granulométrique en prenant comme valeur du pourcenlage en poids, la moitié de celles indiquées par chacue compartiment.

Puis on introduisait trois fois la quantite primitive et la courbe granulométrique était tracée en divisant par trois les indications de l'appareil. On constata que ees trois courbes coincidaient exactement (fig. 5).

Puis l'on prit deux échantillons de même poids, l'un de sable fin, l'autre de sable un peu plus grossier. Ces échantillons furent, tour à tour, introduits dans l'appareil, qui donna leur courbe granulométrique. Ces courbes sont reproduites sur la fig. $6(a, b)$.

Une nouvelle courbe fut alors tracée en additionnant les deux premières. C'est la courbe " $C$ ” du même diagramme. On fit alors un mélange, à parts égales, de ces deux échantillons; ce mélange fut introduit dans l'appareil qui en donna une courbe 
granulométrique (courbe "D " sur la lig. 6). Un constate que cette courbe concorde très bien avec la courbe obtente algébriquement, ce qui confirme la précision de l'appareil pour les analyses granulométriques.

\section{Comparaisons entre les zésultấs obtemus et ceux domzés par d'aulres appareils en usage}

Nous uous sommes proposés de comparer, quant ther fonctionnement, et à leur précision, trois shomotres :

Lappareil à niveat opticue, lappareil de Purr. ef le présent appareil d'Uppax.

A cet effet, huit échantillons furent analyses simultanement sur les trois appareils et on traca leur courbe granulométrique.

Les courbes obtenues par ces appareils pour ces échantillons sont reproduites sur les figures 7 a 14 . La valeu moyenne du diamelre des particules conposant les echantillons ful deduite de leur courbe gramblombtrique respective. Ces valeurs moyennes sont hidqueos dans le tablead ci-dessous:

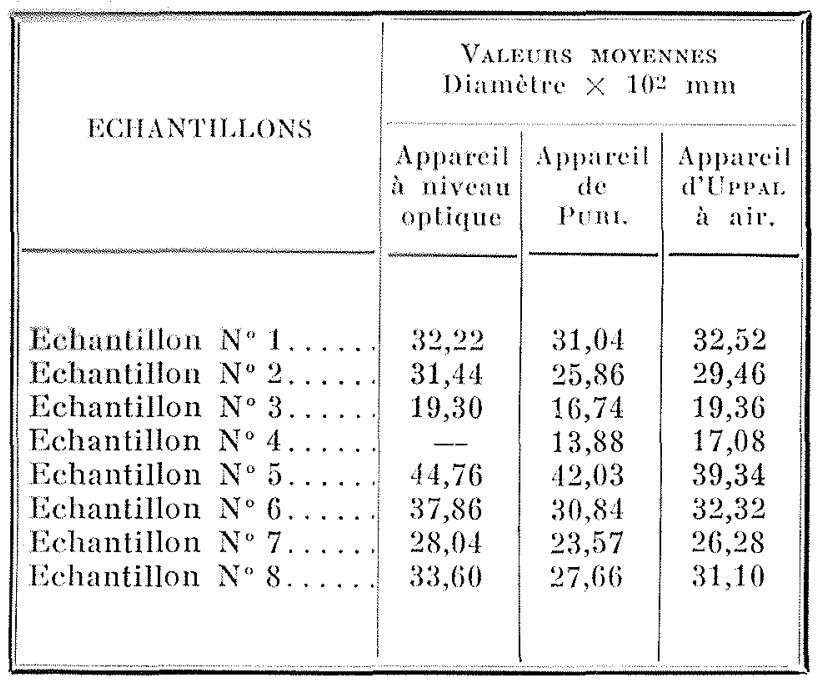

\section{Effet de la hempézcoture}

Nous avons examiné l'effet de la température sur 1e fonctionmement de notre appareil. Nous en avons conclu que les courbes granulometriques obtenues pour un même échantillon à des températures diffèrentes, concordaient exactement. Un écart de tempèrature de $30^{\circ} \mathrm{G}$ apparait sans aucune influence.

Pour certaines stations expérimentales qui peuvent ne pas disposer de courant électrique, nous avons été amenés à modifier le ventilateur. Nous avons réalisé une soufflerie à mancuvre manuelle : entre des mains exercées, l'appareil a donné des résultats relativement précis.

C'est en décembre 1940 que l'appareil fut présenté en fonctionnement à l'Ingénieur en chef du Punjab; ce dernier, favorablement impressionné, en ordonna l'emploi officiel pour les analyses granulométriques. Certaines améliorations furent apportées a la présentation des instruments; c'est ainsi cu'ils furent rendus beaucoup plus légers par l'adoption d'un châssis en aluminium.

Le fonctionnement de l'appareil fut spécialement présenté à divers ingénieur's étrangers venus assister au Congrès Technique du Punjab en 1941. Ils purent l'essayer avec différentes sortes de matériaux, et se montrèrent tout à fait satisfaits.

Parmi les personnalités qui ont minutieusement examiné notre siltomètre, nous citerons:

Mr. Gérald Lacey, Sir Claude Inglis, Dr. Bose, Mr. Hause, Ingénieur Sind, et Mr. Fremjee, X.E.N. Development Sind, puis Directeur de la Station Centrale de Recherches pour l'Hydro-Electricité, les Irrigations et la Navigation à Poona. Peu de temps après, nous recevions des commandes d'appareils de la part de Sir Claude Inams, de Mr. K. K. FrearJEE et d'ailleurs.

Les moyens dont nous disposons à Lahore ne nous permettaient pas d'assurer la construction et l'expédition de nombreux appareils. Nous pûmes cependant envoyer des dessins détaillés de l'appareil, afin que l'on puisse le réaliser sur place.

A la demande du Secrétariat du Central Board of Irrigations, l'appareil fut exposé tel que à l'exposition indienne du Central B. Of.I qui se tint à New-Delhi en 1946.

Liun des anteurs, au cours d'un voyage anx Etats-Unis et en Grande-Bretagne en 1946, eut l'occasion de parler de l'appareil avec d'eminents spécialistes de sédimentation comme le professeur IAne, le professeur Hunter Rovse, de l'Iowa Instilute, et beaucoup d'autres. Ils manifestèrent un vif intérêt pour ce dispositif.

Nous essayons actuellement d'étendre la plage d'utilisation des instruments et de les perfectionner encore. Au lieu de souffler l'air, un dispositif est actuellement à l'étude consistant à aspirer l'air, à partir de l'enceinte expérimentale. 